\title{
A Serious Game (Immunitates) About Immunization: Development and Validation Study
}

Isabela Dantas de Araujo Lima ${ }^{1}$, MSc; Casandra Genoveva Rosales Martins Ponce de Leon ${ }^{2}$, MSc; Laiane Medeiros Ribeiro $^{2}, \mathrm{PhD}$; Izabel Cristina Rodrigues da Silva ${ }^{1}, \mathrm{PhD}$; Danielle Monteiro Vilela ${ }^{3}, \mathrm{PhD}$; Luciana Mara Monti Fonseca ${ }^{4}, \mathrm{PhD}$; Fernanda dos Santos Nogueira de Góes ${ }^{4,5}, \mathrm{PhD}$; Silvana Schwerz Funghetto ${ }^{1}, \mathrm{PhD}$

${ }^{1}$ Graduate Program in Health Sciences and Technologies, Ceilândia College, University of Brasília, Brasília, Brazil

${ }^{2}$ Ceilândia College, University of Brasília, Brasília, Brazil

${ }^{3}$ Centro Universitário Claretiano, Ribeirão Preto, Brazil

${ }^{4}$ Ribeirão Preto College of Nursing, University of São Paulo, Ribeirão Preto, Brazil

${ }^{5}$ MacEwan University, Edmonton, AB, Canada

\section{Corresponding Author:}

Isabela Dantas de Araujo Lima, MSc

Graduate Program in Health Sciences and Technologies

Ceilândia College

University of Brasília

Campus Universitário - Centro Metropolitano, Ceilândia Sul

Brasília, 72220-275

Brazil

Phone: 556131078418

Email: isabeladantas.al@gmail.com

\section{Abstract}

Background: Vaccination is a fundamental part of all levels_-local to worldwide_ - of public health, and it can be considered one of humanity's greatest achievements in the control and elimination of infectious diseases. Teaching immunization and vaccination can be monotonous and tiring. It is necessary to develop new approaches for teaching these themes in nursing school.

Objective: We aimed to develop and validate a serious game about immunization and vaccination for Brazilian nursing students.

Methods: We developed a quiz-type game, Immunitates, using design and educational theoretical models and Brazilian National Health Guidelines. The game's heuristics and content were evaluated with 2 different instruments by a team of experts. A sample of nursing students evaluated the validity of the game's heuristics only. We calculated the content validity index (CVI) for each evaluation.

Results: The study included 49 experts and 15 nursing students. All evaluations demonstrated high internal consistency (Cronbach $\alpha \geq .86$ ). The game's heuristics (experts: CVI 0.75-1.0; students: CVI 0.67-1.0) and the game's contents demonstrated validity (experts: CVI 0.73-1.0). Participants identified some specific areas for improvement in the next version.

Conclusions: The serious game appears to be valid. It is intended as a support tool for nursing students in the teaching-learning process and as a tool for continuing education for nurses.

(JMIR Serious Games 2022;10(1):e30738) doi: $\underline{\text { 10.2196/30738 }}$

\section{KEYWORDS}

educational technology; immunization; nursing education; validation; methodological study; vaccination; public health; nursing students; teaching; education; support tool; continuing education

\section{Introduction}

Vaccination, a fundamental part of public health, is one of humanity's greatest achievements in the control and elimination of infectious diseases [1]. The benefits of vaccines have been proven; in the last few decades, as an example, smallpox was eradicated through immunization [2]. Vaccines have saved lives; reduced the incidence of polio by $99 \%$ in the world; and reduced diseases, disabilities resulting from diseases, and deaths caused by diphtheria, tetanus, and whooping cough [2]. 
Immunization of the population can decrease the transmission of infectious diseases, in turn decreasing hospitalizations, public expenditures on health care, and population mortality, which may increase the life expectancy of a population. Immunization will always be a necessary health action. Each year, 130 million babies are born [3], and they all have the right to receive protection against vaccine-preventable diseases.

In Brazil, it is necessary to abide by the recommended vaccination schedule [4] for children to be considered immunized. Thus, it is important that those responsible for a child are knowledgeable about the importance of vaccination-why the entire population must take the recommended vaccines - and that myths are debunked and explained.

Therefore, it is important that health professionals, especially nurses, have theoretical knowledge that offers a foundation and security to organize and promote health education. In this sense, nursing students must learn enough to provide health education to their future patients. Furthermore, in Brazil, nursing duties in primary care include administering vaccinations and managing everything related to them to ensure the safety of the immunobiological materials, and consequently, that of the patient [5].

In Brazil, the theoretical topics related to vaccination are mostly found in manuals and ordinances-technical texts that can be long, boring, and unappealing-resulting in dense and exhaustive reading for the student. We believe the use of a different methodology (serious games) in the teaching-learning process will help teachers to stimulate learning in the classroom and students to reinforce and review their knowledge on immunization. By using new methodologies, teaching can be more dynamic and the pattern of traditional vertical teaching, wherein the teacher demonstrates and the student repeats, can be broken [6]. Breaking this pattern of traditional education is important given the profile of the current generation of students-they are no longer just listeners but critical protagonists in the process of building knowledge [7,8].

The use of educational technologies in nursing has gradually increased over the years in Finland [9] and in other regions (Norway, other European countries, Asia, and Brazil [10]). To the best of our knowledge, there are no digital serious games related to vaccination in Brazil that are specifically for nursing students and nurses. We aimed to develop serious game about vaccine-preventable diseases and immunization and validate the game's contents and heuristics.

\section{Methods}

\section{Game Development}

\section{Framework}

As a theoretical frame of reference for the creation and development of the game, we used the Elemental Tetrad (Story, Aesthetics, Mechanics, Technology) [11] and the first 3 levels (Remembering, Understanding, and Applying) of the Revised Bloom's Taxonomy [12], as they have been commonly used in studies [13-16] that addressed the development of educational health technologies.

The contents of the game (a database with questions, answers, and feedback) were based on the Brazilian Ministry of Health's Manual of Rules and Procedures for Vaccination [17].

\section{Story}

In the game Immunitates (Figure 1), the player assumes the role of nurse in the vaccination room and answers questions on immunization. When the players correctly answers a sufficient number of questions, their nurse avatar is promoted. The aim is to reach the last level of the game when the nurse reaches the role of Minister of Health.

Feedback on each question is immediate, thus maintaining the user's motivation and engagement in the game [18]. 
Figure 1. Welcome screen.

\section{Immunitates}

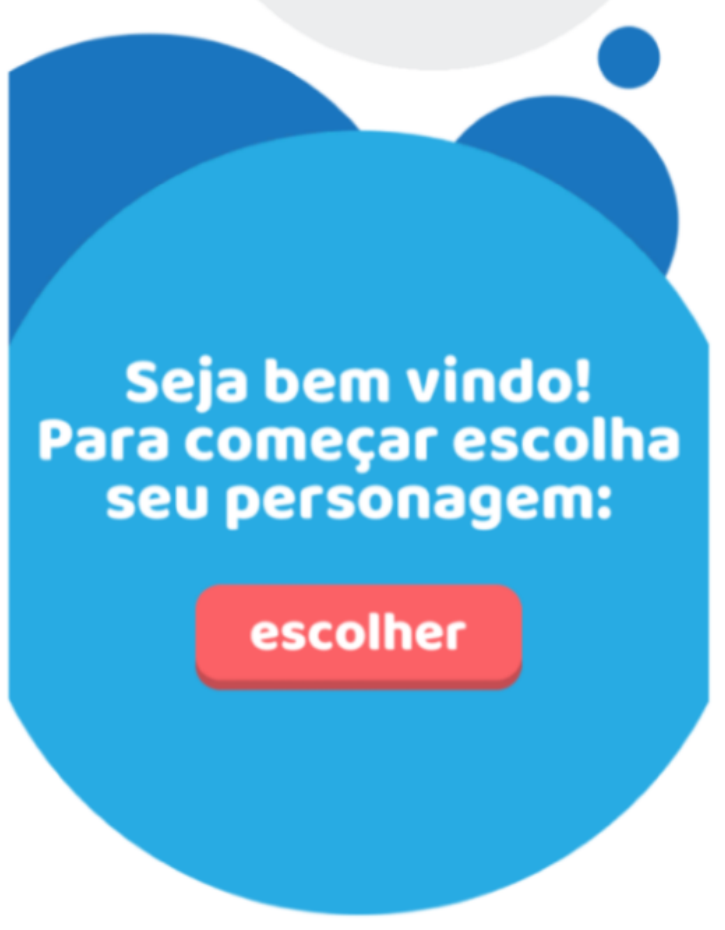

\section{Aesthetics}

The player is asked to choose a female or male avatar (Figure 2 ), which changes job positions as the player advances to the next levels.

Figure 2. Avatar selection screen.

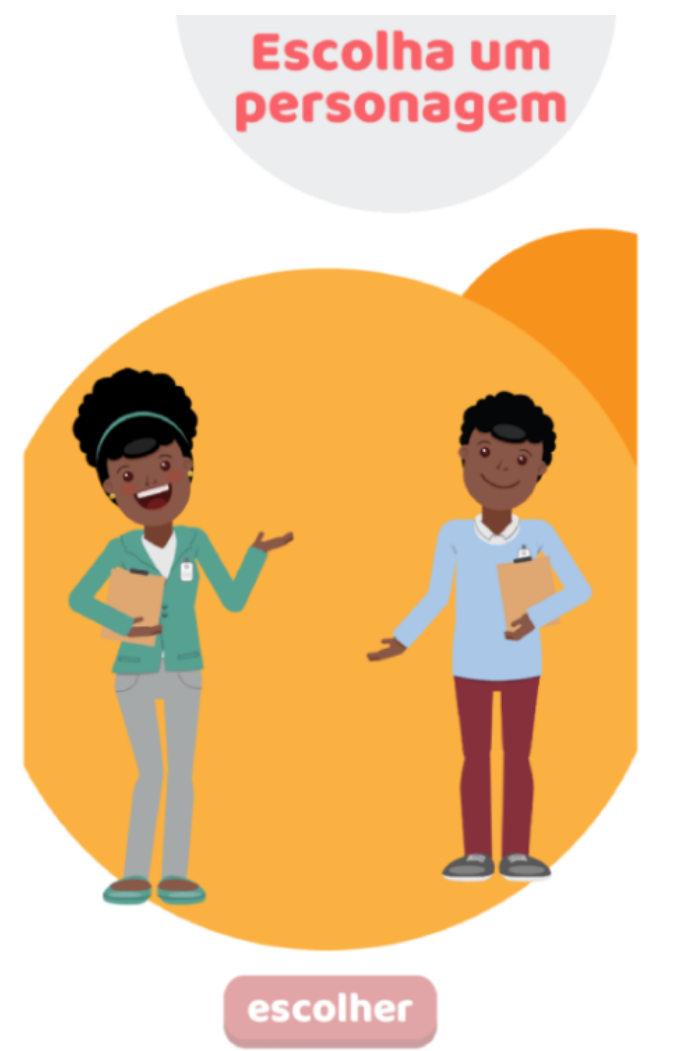




\section{Mechanics}

The game has a quiz format, and players progress by levels (Figures 3-5), which are unlocked as the player answers questions correctly. The game has 7 levels, each corresponding to a job position that the nurse avatar achieves (Figure 6). Each level has a bank of questions, from which a specific number of questions are randomly chosen (Table 1). For example, level 1 has a bank of 5 questions, and each time the player accesses the level, 3 of the 5 questions are chosen. The player must correctly answer at least 1 question for the next level to be unlocked. If the user does not correctly answer the minimum number of questions, they fail the level but can immediately play it again.

Figure 3. Immunitates flowchart.

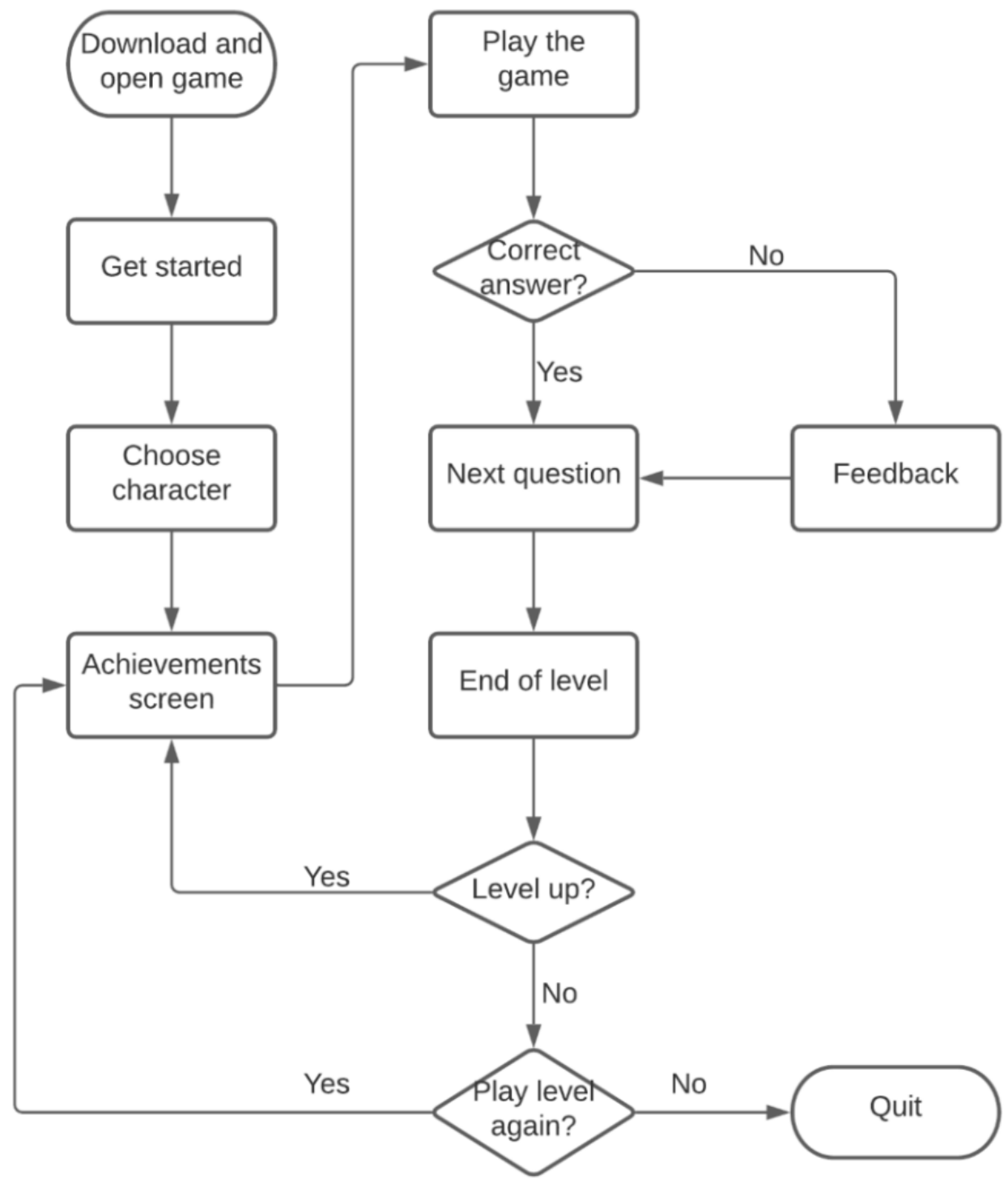


Figure 4. Screen explaining the game's story.

\section{Immunitates}

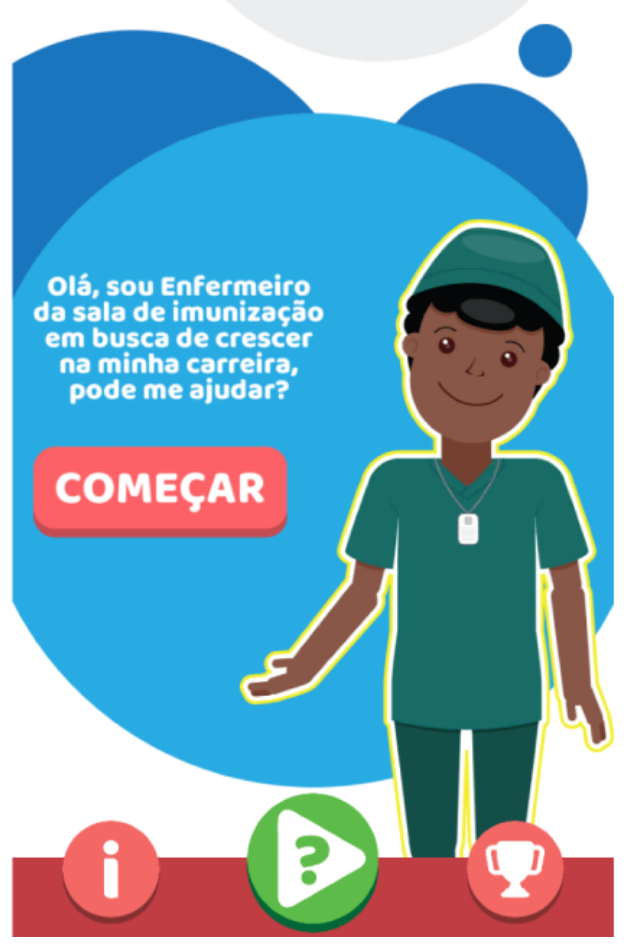

Figure 5. Achievements screen.

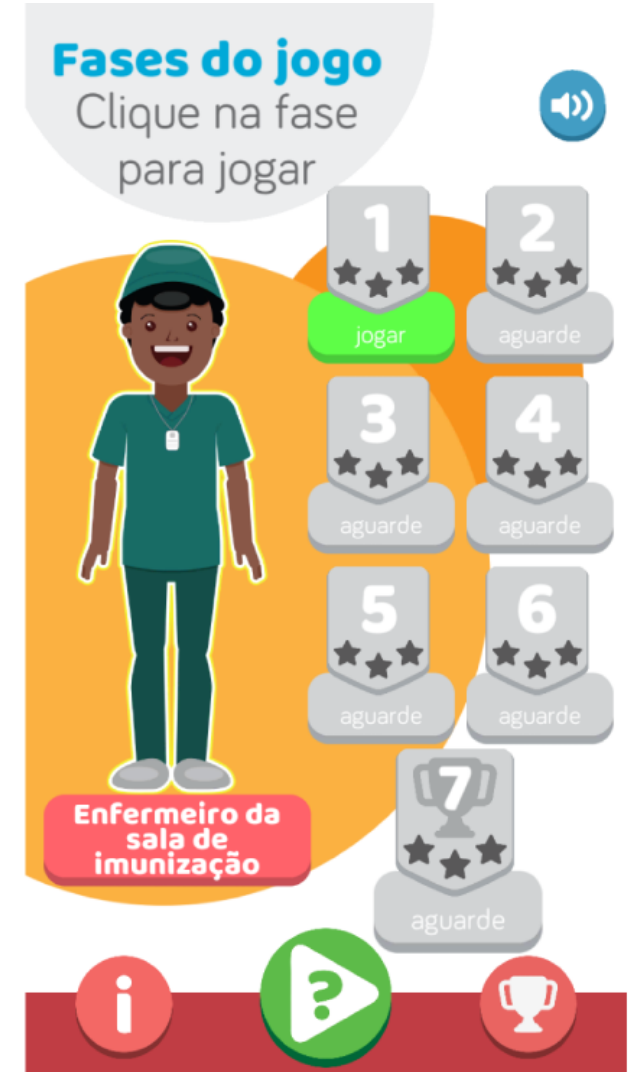


Figure 6. Female and male avatars.
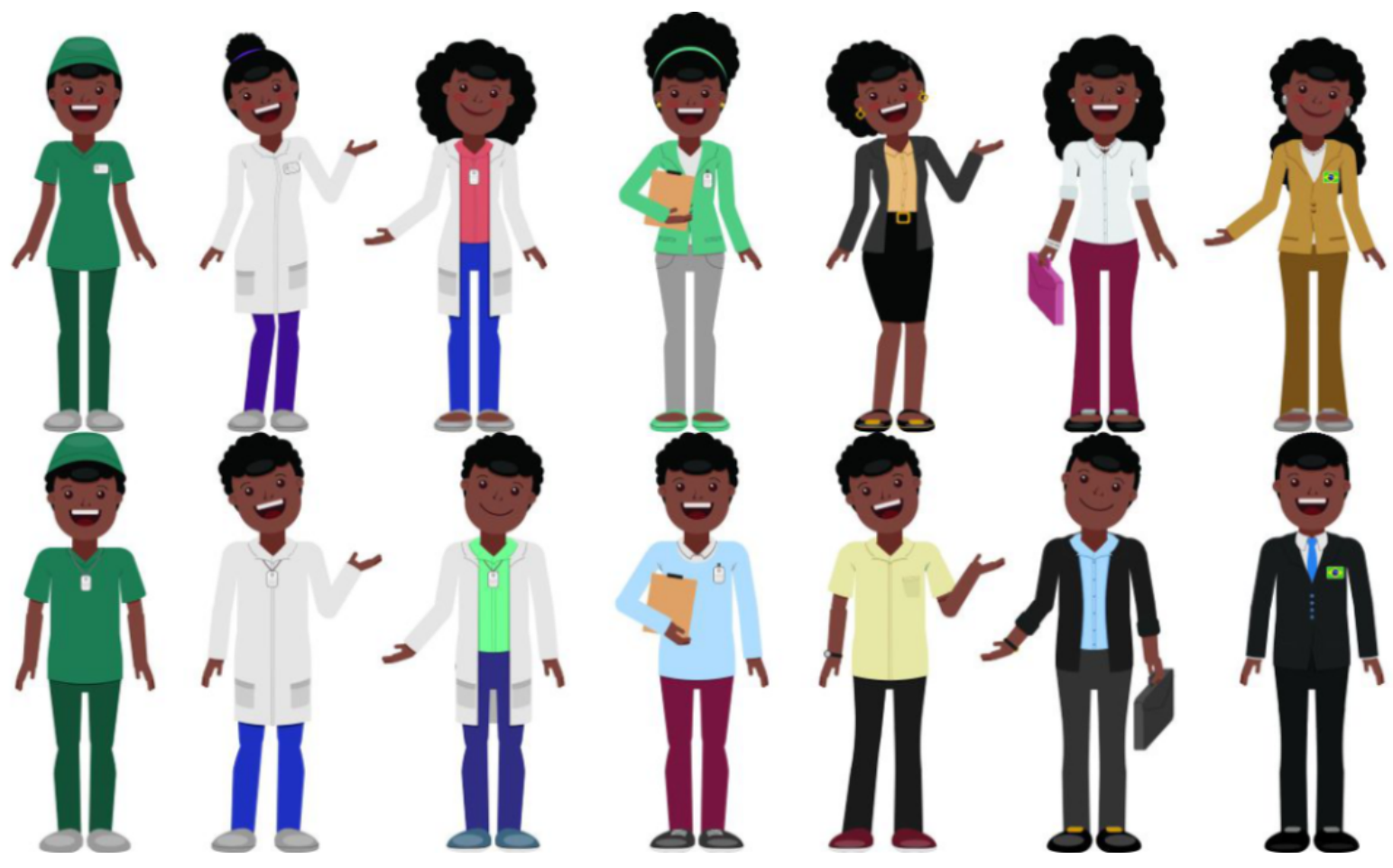

Table 1. Game levels.

\begin{tabular}{llll}
\hline Level & Questions in database, $\mathrm{n}$ & Questions played, $\mathrm{n}$ & $\begin{array}{c}\text { Correctly answered questions to } \\
\text { progress to the next level, } \mathrm{n}\end{array}$ \\
\hline 1 Immunization room nurse & 5 & 3 & 1 \\
2 Nurse manager of the Basic Health Unit & 7 & 5 & 2 \\
3 Director of the Basic Health Unit & 9 & 6 & 3 \\
4 Director of Health Surveillance & 11 & 7 & 4 \\
5 Health secretary & 13 & 9 & 4 \\
6 Director of the National Immunization & 15 & & 5 \\
Program & 20 & 10 & 5 \\
7 Health minister & & 9 & 3 \\
\hline
\end{tabular}

The question database for the entire game consists of 80 questions. For each question, there are 3 options, with only 1 correct option (Figure 7), and text is automatically displayed to explain the correct answer, as automatic rationale feedback, if the player selects the incorrect option (Figure 8). Questions written with direct and simple wording and that require players to remember information were considered easy questions. Questions that require complex clinical reasoning were considered difficult and are presented later on in the game. For better visualization of the question and answer texts, questions could be up to 150 characters long, while each answer and feedback could be up to 120 characters.

Throughout the game, the player listens to a theme song (which can be muted on the achievements screen). The player also has the option to reset the game on the information screen (not pictured), this action restarts the game completely and all progress is lost. 
Figure 7. Correct answer screen.

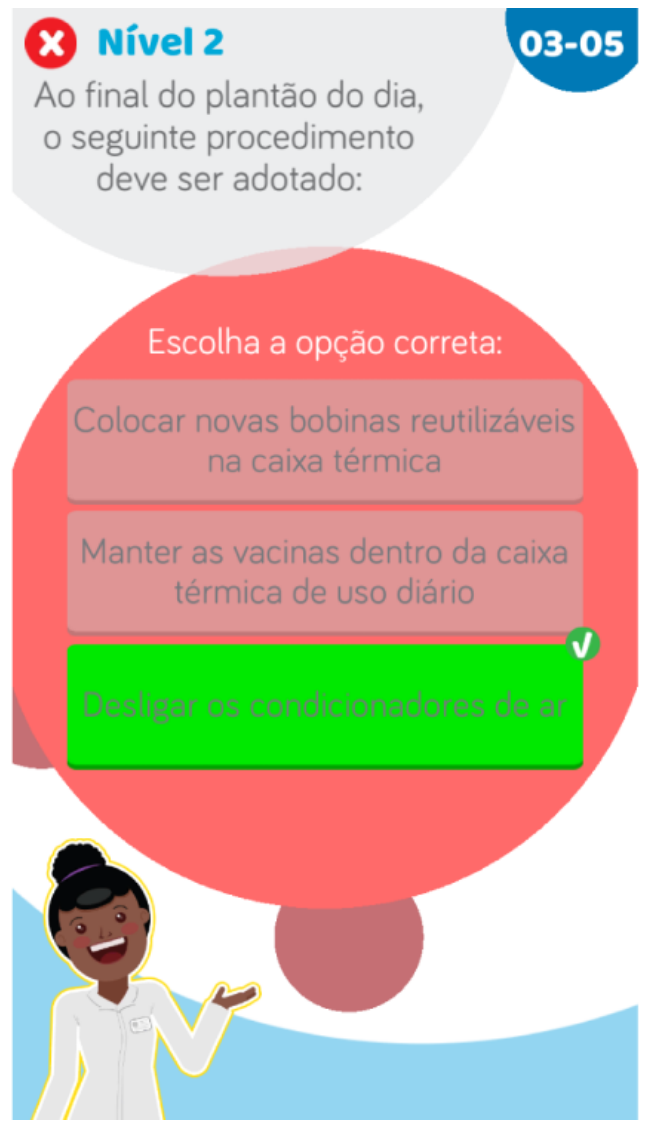

Figure 8. Incorrect answer screen with feedback.

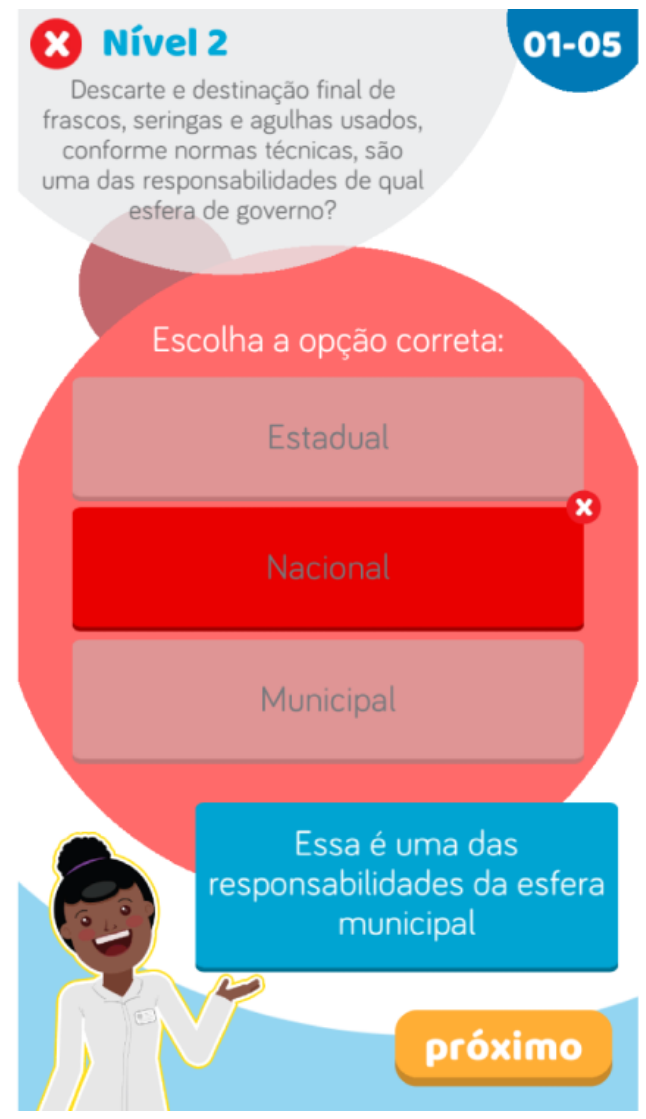




\section{Technology}

The game was programmed in January 2019 using C++ and JavaScript for mobile phones with Android and iOS operating systems; the game is available in Portuguese for free from the Google Play Store and the Apple App Store.

\section{Game Validation}

This study was undertaken with 2 different independent samples: (1) experts in nursing education technologies, nursing games, or immunization and (2) nursing students.

\section{Experts}

Inclusion criteria for experts were adapted from an existing model [19] that is widely used in Brazil to select experts for validation studies [20]. It was a mandatory criterion to have a Bachelor of Science degree in Nursing. An additional criterion was having specialized knowledge, clinical practice, or authorship in areas related to immunization, technology, or health education.

We actively searched 90 public nursing colleges in Brazil for nursing professors who had a history of researching nursing education technologies, nursing games, or immunization. We contacted 983 professors by email, inviting them to validate the game's heuristics and content. The email had 2 different links: one to download the game, and the other to provide demographic information (age, gender, time working as a nurse, and additional degrees or certifications) to indicate that they accepted to be part of the study. Participants received a second email with links to heuristics and content evaluation forms.

\section{Students}

Inclusion criteria for students were being an undergraduate nursing student enrolled at University of Brasília Ceilândia College in the discipline Comprehensive Care for Women and Children's Health at the time of data collection. In this discipline, students learn about the Brazilian vaccination calendar and immunization, and students were invited, during a class, to take part in this study. Students who agreed to participate were sent an email with 3 links: one to download the game, one to provide demographic information (age and gender), and a third to validate the game's heuristics only.

\section{Ethics}

The study was conducted in accordance with the Helsinki Declaration and Resolution 466/2012 [21] of the National Health Council (Brazil). The study was approved by the Research Ethics Committee of Ceilândia College, University of Brasília (CAAE 08595019.2.0000.8093).

\section{Evaluations}

Game heuristics were evaluated by both experts and nursing students using Avaliação Heurística para Jogos Educacionais Digitais (AHJED, Heuristic Evaluation for Digital Educational Games) [22]), which has 8 dimensions-interface, playability, multimedia, artificial intelligence, game's story, educational elements, contents, and educational agent—evaluated on a Likert scale (Multimedia Appendix 1).
Game contents were evaluated by experts using an instrument [23] with 3 dimension-objectives, structure and presentation, and relevance (Multimedia Appendix 2) and by omitting items about functionalities that were neither present nor intended to be present in the game.

Participants also had the option to leave comments about their experience playing the game and suggestions about what could be improved in the next version.

\section{Analysis}

Statistical analysis was performed using SPSS software (version 22; IBM Corp).

The content validity index (CVI) is widely used in the field of health [24-26] and is used to assess the proportion of agreement for an item of an instrument [27]. The index was calculated in 2 ways: For the game heuristics evaluation, the number of agree and strongly agree responses were summed and divided by the total number of responses. For the game content evaluation, the number of adequate and totally adequate were summed and divided by the total number of responses. Items with $\mathrm{CVI} \geq 0.80$ would remain as they are, whereas items with $\mathrm{CVI}<0.80$ should be changed for the next version of the game.

We also calculated Cronbach $\alpha$ [28], a statistical measure that estimates the internal reliability of a questionnaire, for each evaluation (experts' AHJED, students' AHJED, and experts' content). Cronbach $\alpha \geq 70$ was deemed acceptable [29].

\section{Results}

Of those invited, 184 nursing professors provided demographic information in response to the first email, but only 49 completed the game validation and met inclusion criteria; therefore, 49 experts took part in this study. Of the 49 experts, 43 experts $(88 \%)$ were female, and $6(12 \%)$ experts were male. Experts ranged from 28 to 63 years old (mean 44.04 years old), with time working as a nurse ranging from 3 to 40 years. Of 48 students enrolled in the discipline, 15 took part in the study. Of the 15 students, 14 (93\%) students were female, and 1 (7\%) student was male. Students ranged from 20 to 28 years old (mean 22.13 years old).

Overall, the CVI ranged from 0.77 to 0.97 . For heuristics, the CVI ranged from 0.75 to 1 in the expert group and 0.67 to 1 in the student group. Cronbach $\alpha$ was always greater than 0.86 (Table 2; Multimedia Appendix 3).

For content, the CVI ranged from 0.73 to 1 , overall ranging from 0.88 to 0.93 (Table 3). Cronbach $\alpha$ was always greater than 0.89 . Detailed results can be seen on the original tables in the supplementary files (Multimedia Appendix 4).

Participant comments were translated from Portuguese to English by the authors of this study. Not all participants chose to leave a comment. Both experts and students left suggestions related to the content, aesthetics, and their experiences playing the game (Table 4). 
Table 2. Evaluation results for Immunitates heuristics.

\begin{tabular}{lllll}
\hline Dimension & $\begin{array}{l}\text { Experts }(\mathrm{n}=49) \\
\text { Cronbach } \alpha\end{array}$ & Content validity index & $\begin{array}{l}\text { Students }(\mathrm{n}=15) \\
\text { Cronbach } \alpha\end{array}$ & .88 \\
\hline Interface & .87 & 0.90 & .88 & 0.93 \\
Playability & .87 & 0.88 & .88 & 0.94 \\
Multimedia & .87 & 0.87 & .88 & 0.97 \\
Artificial intelligence & .87 & 0.90 & .88 & 0.89 \\
Game's story & .86 & 0.90 & .88 & 0.93 \\
Educational elements & .86 & 0.90 & .88 & 0.87 \\
Contents & .87 & 0.83 & .87 & 0.77 \\
Educational agent & .87 & 0.86 & & 0.76 \\
\hline
\end{tabular}

Table 3. Evaluation results for Immunitates content.

\begin{tabular}{lllll}
\hline Dimension & $\begin{array}{l}\text { Experts }(\mathrm{n}=49) \\
\text { Cronbach } \alpha\end{array}$ & Content validity index & $\begin{array}{l}\text { Students }(\mathrm{n}=15) \\
\text { Cronbach } \alpha\end{array}$ & - \\
\hline $\begin{array}{l}\text { Objectives of the content } \\
\begin{array}{l}\text { Structure and presentation of the } \\
\text { content }\end{array}\end{array}$ & .90 & 0.88 & $-{ }^{\mathrm{a}}$ & - \\
Relevance of the content & .89 & 0.90 & - & - \\
\hline
\end{tabular}

${ }^{\mathrm{a} O n l y}$ experts evaluated the content.

Table 4. Comments and suggestions from experts and nursing students.

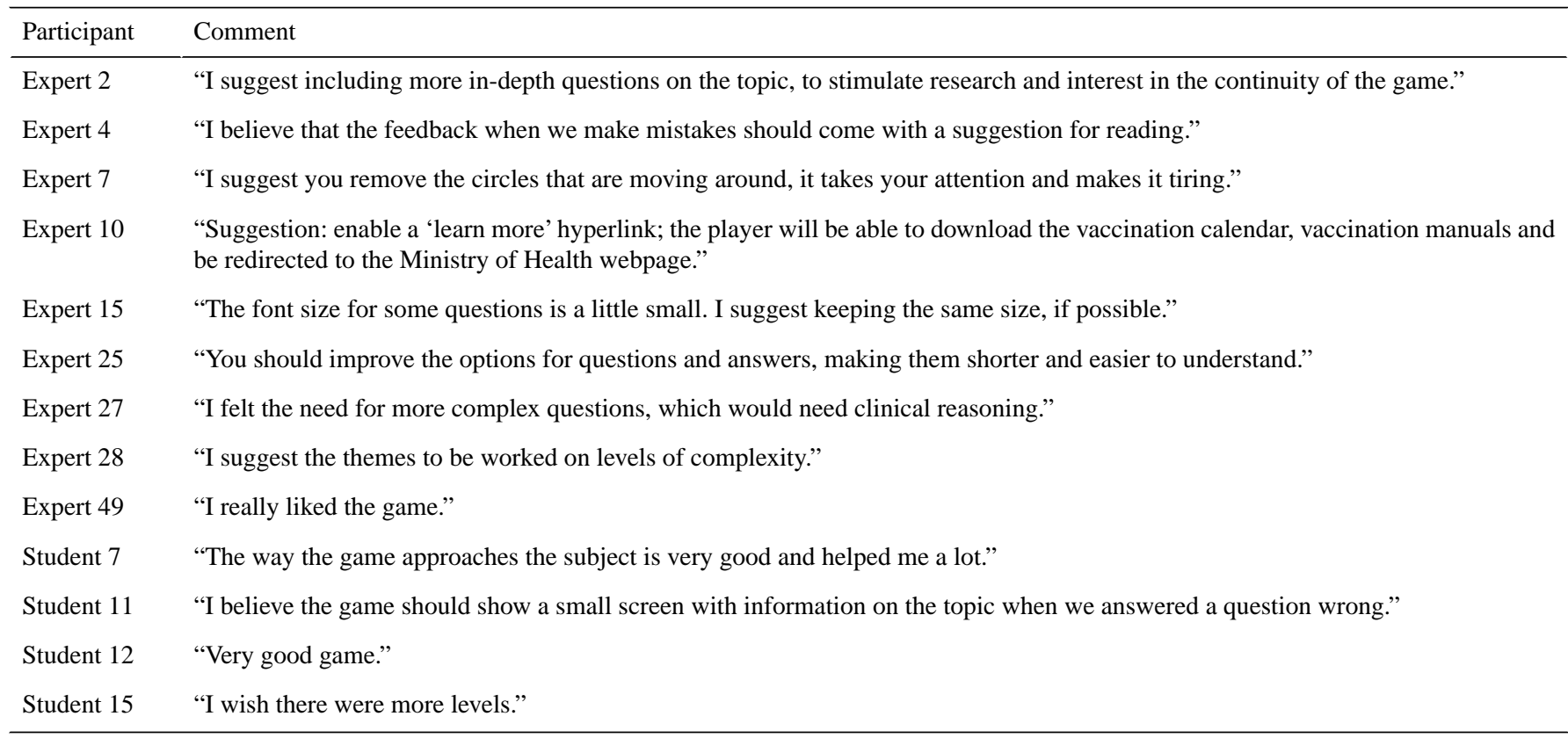

\section{Discussion}

The results present evidence of validity and suggest that the game can be used by both nurses and nursing students alike, as the game was tested and well accepted by them. We noticed that digital serious games about vaccination have up until now been developed for children [30,31].
Evaluations demonstrated high internal consistency (Cronbach $\alpha \geq$.86) [32]. Although most items within the evaluated heuristics were greater than 0.80 , a few-level of difficulty (students: CVI 0.73), partition of the content (students: CVI 0.67), player's performance (students: CVI 0.67), and aesthetics of the game (experts: CVI 0.75; students: CVI 0.67)—did not reach this stipulated number; these features will be reworked for the next version of the game based on suggestions: 
I suggest including more in-depth questions on the topic, to stimulate research and interest in the continuity of the game. [Expert 2]

I suggest you remove the circles that are moving around, it takes your attention and makes it tiring. [Expert 7]

The font size for some questions is a little small. I suggest keeping the same size, if possible. [Expert 15]

I wish there were more levels. [Student 15]

For content, CVI $\geq 0.88$. Still, for some items in groups 1 and 2, CVI values were below expectations. Experts suggested that the content did not instigate change in behavior and attitude (CVI 0.73),

\section{I felt the need for more complex questions, which would need clinical reasoning, [Expert 27]}

and that the messages were not clear or objective (CVI 0.78):

You should improve the options for questions and answers, making them shorter and easier to understand. [Expert 25]

I suggest the themes to be worked on levels of complexity. [Expert 28]

The content will also be reworked for the next version of the game.

The validation of educational technologies has been widely used in Brazil [23-25,33], and worldwide, in countries such as the United Kingdom [34], Canada [35], Italy [36], and Germany [37].

According to Korhonen [38], playability should not be the main objective of a game, although it is necessary for a positive experience, as good playability positively affects the user experience. Our results confirm this, since both experts (CVI 0.87) and students (CVI 0.88) indicated playability was acceptable, and expert and student participants commented on their good experience and how they liked the game:

Very good game. [Student 12]

I really liked the game. [Expert 49]

Content is perhaps the most important part of an educational tool. From participants' suggestions, it was clear that both experts and students would have liked to have an external link that could provide theoretical support as a way to further their knowledge.

Expert 2 suggested including more in-depth questions to stimulate research and interest in the player, which corroborates the findings of a previous study [39], namely, that the difficulty of a game can affect player motivation. The game must have challenging elements but still leave the player confident enough to overcome them. Experts 27 and 28 also commented on the need for more complex questions that would need clinical reasoning, but expert 25 thought that the questions should be simpler, shorter, and easier to understand.

However, players may have different skills; what is classified as difficult, a player may perceive to be very easy or very difficult, which can lead players to feeling frustrated or even bored, which decreases their motivation and engagement with a game [40].

It is also true that technology-specific problems can arise when using educational technologies, such as issues downloading or installing and log-in, audio, and video-related problems. Students can find this method of teaching to be unengaging or they may simply not find the time to study using these new tools [41].

During the COVID-19 pandemic, when teachers and students worldwide had to stay at home, a new challenge arose in health care education. Somehow training in a field that is traditionally taught with a hands-on approach had to continue in alternative manners. During the first wave, educators began to utilize new educational technologies to continue teaching. The impact of these technologies in the field of health care education is unique because educators must continue training future professionals who will soon be working in-person at hospitals amid the pandemic, despite social distancing [42]. Although many educators have had to improvise and quickly learn how to use these new technologies during the COVID-19 pandemic, the use of technology in the teaching-learning process should be driven by pedagogical needs and goals and not by technological pressures [43].

When elements of gamification, such as points, achievements, and levels, are incorporated into the undergraduate teaching-learning process, there is a positive effect on student motivation and performance [44]. Motivation is the state in which the individual feels moved to do something. According to the Self-Determination Theory, motivation is separated into levels (from a little to a lot of motivation) and orientation (intrinsic and extrinsic motivation). In extrinsic motivation, the individual seeks reward or escapes punishment, whereas intrinsic motivation refers to pleasure to do or an inherent personal satisfaction [45]. Harandi [46] highlights that when students are motivated to learn, they are likely to be involved; when they are involved, they are more likely to achieve educational goals.

There were a few limitations in this study. The budget available for the construction of the game did not allow for all intended features to be included in this version. Suggestions made by the participants were documented so that, in the future, they can be implemented.

The number of students who participated was small, which can alter the results of the evaluation of educational technology. Students who had already completed the discipline Comprehensive Care for Women and Children's Health were not included, even though they already had the necessary knowledge to validate the game, because these students were engaged in course work outside the university, and we had difficulty contacting them.

In future studies, we intend to test the effectiveness of the game by comparing knowledge acquisition from class only compared with that from the combination of class and playing the game to determine if this game is useful in helping nursing students. We also intend to test graduate nurses' satisfaction with the game and knowledge acquisition from the game to determine if it is useful to this target audience. With these results, we 
would be able to categorically affirm that the game is useful to both nurses and nursing students.

Immunitates presents evidence of validity, even though some areas of the game require improvement. Immunitates is designed to be a support tool for nursing students (ie, not to replace face-to-face class instruction) and to be a tool for continuing education for nurses.

\section{Acknowledgments}

We would like to deeply thank all participants and University of Brasília for supporting this study. This study was financed by Coordenação de Aperfeiçoamento de Pessoal de Nível Superior (Finance Code 001) and Fundação de Apoio à Pesquisa do Distrito Federal (9721.56.32761.05042016).

\section{Conflicts of Interest}

None declared.

\section{Multimedia Appendix 1}

Instrument for heuristic validation.

[DOCX File, 16 KB-Multimedia Appendix 1]

\section{Multimedia Appendix 2}

Instrument for content validation.

[DOCX File, 14 KB-Multimedia Appendix 2]

\section{Multimedia Appendix 3}

Heuristic validation results.

[DOCX File, 22 KB-Multimedia Appendix 3]

\section{Multimedia Appendix 4}

Content validation results.

[DOCX File, 15 KB-Multimedia Appendix 4]

\section{References}

1. Lessa SC, Schramm FR. Individual versus collective protection: bioethical analysis of the national program of mass child vaccination. Cien Saude Colet 2015 Jan;20(1):115-124 [FREE Full text] [doi: 10.1590/1413-81232014201.14882013] [Medline: 25650604]

2. Global vaccine action plan 2011-2020. PATH.: World Health Organization; 2013. URL: https://www.who.int/publications/ i/item/global-vaccine-action-plan-2011-2020 [accessed 2021-03-04]

3. 2018 assessment report of the global vaccine action plan: strategic advisory group of experts on immunization. World Health Organization. 2018. URL: https://apps.who.int/iris/handle/10665/276967 [accessed 2021-03-04]

4. Fernandes ACN, Gomes KRO, de Araújo TME, Moreira-Araújo RSR. Analysis of vaccination status of preschool children in Teresina (PI), Brazil. Rev Bras Epidemiol 2015 Dec;18(4):870-882 [FREE Full text] [doi:

10.1590/1980-5497201500040015] [Medline: 26982301]

5. Queiroz SA, Moura ERF, Nogueira PSF, Oliveira NC, Pereira MMQ. The nursing team service at the vaccination room and working conditions in such places. Revista da Rede de Enfermagem do Nordeste (Revista Rene) 2009;10(4):123-135 [FREE Full text]

6. Silveira MS, Cogo ALP. The contributions of digital technologies in the teaching of nursing skills: an integrative review. Rev Gaucha Enferm 2017 Jul 13;38(2):e66204 [FREE Full text] [doi: 10.1590/1983-1447.2017.02.66204] [Medline: 28723986]

7. Jacondino MB, Silveira DN, Martins CL, Coimbra VCC. Teaching-learning process of the nursing student and the learning styles. Revista de Estilos de Aprendizagem 2015;8(15):31-50 [FREE Full text]

8. Baquião LSM, Almeida AM. The student as protagonist of his learning: an experience report. Brazilian Appl Sci Rev 2018;2(5):1778-1782 [FREE Full text]

9. Koivisto J, Niemi H, Multisilta J, Eriksson E. Nursing students' experiential learning processes using an online 3D simulation game. Educ Inf Technol 2015 Nov 28;22(1):383-398. [doi: 10.1007/s10639-015-9453-x]

10. Fernandes CSNS, Ângelo M. Games-playing strategies used in nursing - an integrative review. Av Enferm 2018 Jan 01;36(1):88-98 [FREE Full text] [doi: 10.15446/av.enferm.v36n1.63553]

11. Schell J. The Art of Game Design: A Book of Lenses. USA: Elsevier; 2008. 
12. Krathwohl DR. A revision of Bloom's axonomy: an overview. Theory Pract 2010 Jun 24;41(4):212-218. [doi: $10.1207 / \mathrm{s} 15430421$ tip4104 2]

13. Dias JD, Sorrentino GS, Beder DM, Mekaro MS, Santiago DL, Bordini RA, et al. DIGESTOWER: jogo educacional para auxiliar o enfrentamento da obesidade infantil. In: Nuevas Ideas en Informática Educativa. 2014 Presented at: TISE 2014; 2014; Fortaleza, Brazil p. 309-317 URL: http://www.tise.cl/volumen10/TISE2014/tise2014 submission 297.pdf

14. Tan AJQ, Lee CCS, Lin PY, Cooper S, Lau LST, Chua WL, et al. Designing and evaluating the effectiveness of a serious game for safe administration of blood transfusion: a randomized controlled trial. Nurse Educ Today 2017 Aug;55:38-44. [doi: 10.1016/j.nedt.2017.04.027] [Medline: 28521248]

15. Johnsen HM, Fossum M, Vivekananda-Schmidt P, Fruhling A, Sletteb $\varnothing$. Teaching clinical reasoning and decision-making skills to nursing students: design, development, and usability evaluation of a serious game. Int J Med Inform 2016 Oct;94:39-48. [doi: 10.1016/j.ijmedinf.2016.06.014] [Medline: 27573310]

16. Domingues AN, Guimarães ACP, Silva AFS, Esteves JGSF, Lotufo ML, Santiago DL, et al. Desenvolvimento De Jogo Educativo Sobre Segurança Do Paciente Para Ensino Profissionalizante De Enfermagem. 2014 Presented at: SIEDEnPED - Simpósio Int Educ a Distância e Encontro Pesqui em Educ a Distância; 2014; São Carlos, Brazil URL: http://www. sied-enped2014.ead.ufscar.br/ojs/index.php/2014/article/view/609

17. Manual of Rules and Procedures for Vaccination. Brazil: Ministério da Saúde; 2014. URL: https://bvsms.saude.gov.br/bvs/ publicacoes/manual procedimentos vacinacao.pdf

18. Zeng J, Parks S, Shang J. To learn scientifically, effectively, and enjoyably: a review of educational games. Human Behav Emerg Tech 2020 Apr 06;2(2):186-195. [doi: 10.1002/hbe2.188]

19. Fehring R. The Fehring model. In: Classification of Nursing Diagnoses - Proceedings of the Tenth Conference. Philadelphia: Lippincott; 1992:55-62.

20. Melo RP, Moreira RP, Fontenele FC, Aguiar ASC, Joventino ES, Carvalho EC. Criteria for selection of experts for validation studies of nursing phenomena. Rev Rene 2011;12(2):424-431 [FREE Full text]

21. Resolução No 466, de 12 de dezembro de 2012, que trata de pesquisas em seres humanos e atualiza a Resolução 196. Conselho Nacional de Saúde. 2012. URL: https://conselho.saude.gov.br/resolucoes/2012/Reso466.pdf [accessed 2021-09-24]

22. Azevêdo M, Rousy D, Siebra C. AHJED - Avaliação Heurística para Jogos Educacionais Digitais. In: Nuevas Ideas en Informática Educativa. 2018 Presented at: TISE 2018; 2018; Santiago, Chile p. 126-136 URL: http://www.tise.cl/Volumen14/ TISE2018/126.pdf

23. Teixeira E, Martins TDR, Miranda PO, Cabral BG, Costa e Silva BA, Rodrigues LSS. Educational technology on postpartum care: development and validation. Revista Baiana de Enfermagem 2016 Jun 15;30(2):1-10 [FREE Full text] [doi: 10.18471/rbe.v30i2.15358]

24. Jesus EBD, Esteves AVF, Teixeira E, Medeiros HP, Nascimento MHD, Sabóia VM. Validação de tecnologia educacional sobre fototerapia para orientar familiares de neonatos ictéricos [Validation of educational technology on phototherapy to guide family members of icteric neonates] [Validación de tecnología educativa sobre fototerapia para orientar a familiares de neonatos ictéricos]. Rev Enferm UERJ 2018 Dec 30;26:1-7 [FREE Full text] [doi: 10.12957/reuerj.2018.21789]

25. Benevides JL, Coutinho JFV, Pascoal LC, Joventino ES, Martins MC, Gubert FA, et al. Development and validation of educational technology for venous ulcer care. Rev Esc Enferm USP 2016 Apr;50(2):309-316 [FREE Full text] [doi: 10.1590/S0080-623420160000200018] [Medline: 27384212]

26. Pereira FGF, Silva DV, Sousa LMO, Frota NM. Building a digital application for teaching vital signs. Rev Gaucha Enferm 2016 Jun;37(2):1-7 [FREE Full text] [doi: 10.1590/1983-1447.2016.02.59015] [Medline: 27356806]

27. Alexandre NMC, Coluci MZO. Content validity in the development and adaptation processes of measurement instruments. Cien Saude Colet 2011 Jul;16(7):3061-3068 [ㅌREE Full text] [doi: 10.1590/s1413-81232011000800006] [Medline: 21808894]

28. Hora HRM, Monteiro GTR, Arica J. Confiabilidade em questionários para qualidade: um estudo com o coeficiente alfa de Cronbach. Produto \& Produção 2010 Jun 24;11(2):85-103 [FREE Full text] [doi: 10.22456/1983-8026.9321]

29. Cronbach LJ. Coefficient alpha and the internal structure of tests. Psychometrika 1951 Sep;16:297-334. [doi: 10.1007/BF02310555]

30. Monteiro JA, de Paula AA, Nascimento Júnior AF. A report of experience in the initial teacher training: a game for the teaching of vaccine through a historical perspective. Rev Eletrônica Ludus Sci 2019;3(1):113-123 [FREE Full text] [doi: 10.30691/relus.v3i1.1683]

31. Pinto CS, Carvalho C, Rodrigues MAF. Imunização: Um Jogo Sério para Proteção de Crianças Contra as Doenças. 2016 Presented at: 15th Brazilian Symposium on Computer Games and Digital Entertainment (SBGames); 2016; São Paulo, Brazil p. 947-954 URL: http://www.sbgames.org/sbgames2016/downloads/anais/157384.pdf

32. Freitas ALP, Rodrigues SG. A avaliação da confiabilidade de questionários: uma análise utilizando o coeficiente alfa de Cronbach. 2005 Presented at: XII SIMPEP; 2005; Bauri, Brazil. [doi: 10.13140/2.1.3075.6808]

33. Marques TVF. Construction and validation of educational technology: innovations in the method of teaching and learning. University of Brasília. 2018. URL: https://repositorio.unb.br/handle/10482/39263 [accessed 2021-03-17] 
34. Zhai C, Alderisio F, Slowinski P, Tsaneva-Atanasova K, di Bernardo M. Design and validation of a virtual player for studying interpersonal coordination in the mirror game. IEEE Trans Cybern 2018 Mar;48(3):1018-1029. [doi: 10.1109/TCYB.2017.2671456] [Medline: 28287998]

35. Sauvé L, Renaud L, Kaufman D, Duplàa E. Validation of the Educational Game for Seniors: "Live Well, Live Healthy!". 2015 Feb Presented at: International Educational Technology Conference (IETC); September 3-5; Chicago p. 674-682. [doi: 10.1016/j.sbspro.2015.01.526]

36. Savazzi F, Isernia S, Jonsdottir J, Di Tella S, Pazzi S, Baglio F. Engaged in learning neurorehabilitation: development and validation of a serious game with user-centered design. Comput Educ 2018 Oct;125:53-61. [doi: 10.1016/j.compedu.2018.06.001]

37. Kowalewski K, Hendrie JD, Schmidt MW, Proctor T, Paul S, Garrow CR, et al. Validation of the mobile serious game application Touch Surgery for cognitive training and assessment of laparoscopic cholecystectomy. Surg Endosc 2017 Oct;31(10):4058-4066. [doi: 10.1007/s00464-017-5452-x] [Medline: 28281111]

38. Korhonen H. Evaluating playability of mobile games with the expert review method. University of Tampere. 2016. URL: https://trepo.tuni.fi/bitstream/handle/10024/99584/978-952-03-0205-4.pdf?sequence=3 [accessed 2021-03-04]

39. Schadenberg BR, Neerincx MA, Cnossen F, Looije R. Personalising game difficulty to keep children motivated to play with a social robot: a Bayesian approach. Cogn Syst Res 2017 Jun;43:222-231. [doi: 10.1016/j.cogsys.2016.08.003]

40. Perez LJF, Calla LAR, Valente L, Montenegro AA, Clua EWG. Dynamic game difficulty balancing in real time using evolutionary fuzzy cognitive maps. 2015 Presented at: 14th Brazilian Symposium on Computer Games and Digital Entertainment (SBGames); 2015; Piauí, Brazil p. 24-32. [doi: 10.1109/SBGames.2015.17]

41. Dhawan S. Online learning: a panacea in the time of COVID-19 crisis. J Educ Technol Syst 2020 Jun 20;49(1):5-22 [FREE Full text] [doi: 10.1177/0047239520934018]

42. Chatterjee I, Chakraborty P. Use of information communication technology by medical educators amid COVID-19 pandemic and beyond. J Educ Technol Syst 2020 Oct 20;49(3):310-324 [FREE Full text] [doi: 10.1177/0047239520966996]

43. Christopoulos A, Sprangers P. Integration of educational technology during the covid-19 pandemic: an analysis of teacher and student receptions. Cogent Educ 2021 Aug 12;8(1):1-27 [FREE Full text] [doi: 10.1080/2331186x.2021.1964690]

44. Lister M. Gamification: The effect on student motivation and performance at the postsecondary level. Issues Trends Educ Technol 2015;3(2):1-22 [FREE Full text] [doi: 10.2458/azu itet v3i2 lister]

45. Porto RC, Gonçalves MP. Motivation and academic involvement: a study with university students. Psicol Esc Educ 2017 Dec;21(3):515-522 [FREE Full text] [doi: 10.1590/2175-35392017021311192]

46. Harandi SR. Effects of e-learning on students' motivation. Procedia Soc Behav Sci 2015 May;181:423-430 [FREE Full text] [doi: 10.1016/j.sbspro.2015.04.905]

\section{Abbreviations}

AHJED: Avaliação Heurística para Jogos Educacionais Digitais (Heuristic Evaluation for Digital Educational Games)

CVI: content validity index

Edited by $N$ Zary; submitted 26.05.21; peer-reviewed by M Das, F Cruz, R Zaini, M Suppan; comments to author 10.09.21; revised
version received 27.09.21; accepted 12.10.21; published 18.02.22
Please cite as:
Lima IDDA, Ponce de Leon CGRM, Ribeiro LM, Silva ICRD, Vilela DM, Fonseca LMM, Góes FDSND, Funghetto SS
A Serious Game (Immunitates) About Immunization: Development and Validation Study
JMIR Serious Games 2022;10(1):e30738
URL: $\underline{\text { https://games.jmir.org/2022/1/e30738 }}$
doi: $10.2196 / 30738$
PMID:

CIsabela Dantas de Araujo Lima, Casandra Genoveva Rosales Martins Ponce de Leon, Laiane Medeiros Ribeiro, Izabel Cristina Rodrigues da Silva, Danielle Monteiro Vilela, Luciana Mara Monti Fonseca, Fernanda dos Santos Nogueira de Góes, Silvana Schwerz Funghetto. Originally published in JMIR Serious Games (https://games.jmir.org), 18.02.2022. This is an open-access article distributed under the terms of the Creative Commons Attribution License (https://creativecommons.org/licenses/by/4.0/), which permits unrestricted use, distribution, and reproduction in any medium, provided the original work, first published in JMIR Serious Games, is properly cited. The complete bibliographic information, a link to the original publication on https://games.jmir.org, as well as this copyright and license information must be included. 